\title{
ADSORPTION ISOTHERM STUDIES ON ACID ORANGE-10 DYE REMOVAL USING CERIUM DIOXIDE NANOPARTICLES
}

\author{
Harry Budiman and Oman Zuas* \\ Research Centre for Chemistry, Indonesian Institute of Science (RCChem-LIPI), \\ Kawasan PUSPIPTEK Serpong, 15314 Tangerang, Banten, Indonesia
}

Received July 17, 2014; Accepted August 21, 2014

\begin{abstract}
The adsorption capacity of AO-10 from aqueous solution onto $\mathrm{CeO}_{2}-\mathrm{NPs}$ was investigated under various reaction parameters. Batch mode experiments were conducted to assess the potential of the $\mathrm{CeO}_{2}-\mathrm{NPs}$ as adsorbent for the removal of AO-10 dye from aqueous solution. Equilibrium isotherm studies were carried out under an optimum reaction condition (i.e., AO-10 dye concentration $=15 \mathrm{mg} / \mathrm{L}, \mathrm{CeO}_{2}-\mathrm{NPS}$ dosage $=2 \mathrm{~g} / \mathrm{L}, \mathrm{pH}$ of dye solution = 2) obtained from this study. The equilibrium data obtained were fitted to Langmuir, Freundlich, and Redlich-Peterson isotherm models. The results shows that, the linear transform model provided the highest regression coefficient $\left(R^{2}=0.991\right)$ with the Langmuir model. The maximum monolayer adsorption capacity was found to be $33.33 \mathrm{mg} / \mathrm{g}$ at $30^{\circ} \mathrm{C}$, which is higher than some data from published literature.
\end{abstract}

Keywords: dye; adsorption; isotherms; $\mathrm{CeO}_{2}$

\section{ABSTRAK}

Kemampuan adsorpsi $\mathrm{AO}-10$ dari larutan oleh $\mathrm{CeO}_{2} \mathrm{NPs}$ telah diteliti pada berbagai macam parameter reaksi. Eksperimen dilakukan dengan metode batch untuk mengevaluasi kemampuan $\mathrm{CeO}_{2}-\mathrm{NPs}$ sebagai adsorben untuk penghilangan AO-10 dalam larutan. Studi kesetimbangan isotermal dilakukan pada kondisi optimum reaksi yaitu konsentrasi zat warna (AO-10 $=15 \mathrm{mg} / \mathrm{L}$, dosis $\mathrm{CeO}_{2}-\mathrm{NPS}=2 \mathrm{~g} / \mathrm{L}, \mathrm{pH}$ larutan zat warna $\left.=2\right)$. Data kesetimbangan yang diperoleh dicocokkan dengan model isoterm Langmuir, Freundlich dan Redlich-Peterson. Hasil menunjukkan bahwa model linear memberikan nilai koefisien regresi tertinggi $\left(R^{2}=0,991\right)$ pada model Lagmuir. Kapasitas adsorpsi maksimum lapisan tunggal didapat sebesar $33,33 \mathrm{mg} / \mathrm{g}$ pada suhu $30^{\circ} \mathrm{C}$, dimana nilainya lebih tinggi dibandingkan dengan beberapa data dari literatur yang sudah terpublikasi.

Kata Kunci: zat warna; serapan; isotermal; $\mathrm{CeO}_{2}$

\section{INTRODUCTION}

Among the aqueous environmental related issues, water pollution by synthetic dyes from industries might be one of the most serious problems. As reported in many literatures, hundred thousand tons of commercial dyes are produced annually and most of them are used by industries to color their product [1-3]. Water pollution by synthetic dyes can be occurred because high percentage of colored industrial effluents is discharged directly into aqueous environment [4-5], which further can potentially threat the aqueous ecosystem because they are aesthetic pollutants, resistant to aerobic digestion, stable to light heat and oxidizing agents, and they can hinder the light penetration required for the aqueous biological processes [6-8]. In addition, the industrial effluents containing colored textile dyes may cause toxic, carcinogenic, or mutagenic for the aquatic life. In this regards, a proper treatment of industrial effluence (waste) containing textile dye before discharge is crucial. For the treatment purposes, numerous treatment methods have been proposed including chemical coagulation, anaerobic reduction, aerobic oxidation, membrane filtration, photo-degradation and adsorption methods [3,7-10]. Among the reported technologies, the adsorption method provides an attractive technique especially if the adsorbent has high adsorption property [11]. In this regards, nonconventional metal oxide-based adsorbent have been reported to be important materials for the removal of dyes from aqueous solution such as $\mathrm{Mg}-\mathrm{Fe}-\mathrm{CO}_{3}$ layer double hydroxide [12], $\mathrm{Cu}-\mathrm{TiO}_{2}$ composite [13], modified magnetic silica [14], graphene oxide- $\mathrm{F}_{3} \mathrm{O}_{4}$ [15], magnetic $\mathrm{ZnFe}{ }_{2} \mathrm{O}_{4}$ [16], and chitosan- $\mathrm{ZnO}$ nanoparticle [17].

Recently, Zuas et al. [18] found that $\mathrm{CeO}_{2}$ could be potentially used as an efficient adsorbent for the removal of synthetic organic dyes in aqueous solution. In this study, the removal of $\mathrm{AO}-10$ dye using $\mathrm{CeO}_{2-}$ was analyzed under different reaction parameters (i.e.,

* Corresponding author. Tel/Fax : +62-21-7560929/ 7560549

Email address : oman.zuas@lipi.go.id

Harry Budiman and Oman Zuas 
changing the initial AO-10 dye concentration, changing the $\mathrm{CeO}_{2}-\mathrm{NPs}$ dosage, changing the initial $\mathrm{pH}$ of the dye solution, changing the reaction time, and changing the concentration of ionic strength added in the reaction solution). However, in order to estimate practical adsorption capacity, therefore, the information on adsorption equilibrium is important. The equilibrium studies that give the capacity of both adsorbent and adsorbate are described by adsorption isotherm. In general, the adsorption isotherm is the ratio between the quantity adsorbate adsorbed on the surface of adsorbent and the remaining in solution at fixed temperature at equilibrium. The suitable isotherm model that explains the adsorption process is given separately, where the experimental data were analyzed using Langmuir, Freundlich, and Redlich Peterson isotherm.

\section{EXPERIMENTAL SECTION}

\section{Materials}

In this study, the powdered cerium dioxide nanoparticles (hereafter called $\mathrm{CeO}_{2}$-NPs) having 10-16 $\mathrm{nm}$ in particles diameter was the same batch with the $\mathrm{CeO}_{2}-\mathrm{NPs}$ used in our previous study [18]. Acid Orange10 dye (AO-10, $\mathrm{C}_{16} \mathrm{H}_{10} \mathrm{~N}_{2} \mathrm{O}_{7} \mathrm{~S}_{2} \mathrm{Na2}$, C.I. 16230, CAS 1936-358-4, Sigma-Aldrich) was used as a model pollutant (adsorbate) and its chemical structure is shown in Fig. 1. Acid orange is a synthetic azo dye used many staining formulation. This dye is not regarded as chronic toxic, but it can have some harmful effect including skin irritation, serious eye irritation, and respiratory irritation [19]. Deionized water (17.5 M $2 . \mathrm{cm}$ of resistivity) was produced using a Milli-Q water purified system (Millipore Corp) and used in all experiment runs.

\section{Procedure}

\section{Adsorption of AO-10 dye using $\mathrm{CeO}_{2}-\mathrm{NPs}$}

Adsorption testing of $\mathrm{AO}-10$ dye by $\mathrm{CeO}_{2}-\mathrm{NPs}$ was conducted using batch experimental method. Typically, $0.01 \mathrm{~g}$ of $\mathrm{CeO}_{2}-\mathrm{NPs}$ was transferred into $15 \mathrm{~mL}$ capped glass tube containing $10 \mathrm{~mL}$ AO-10 dye solution. Subsequently, the tube was placed in a Cetromat WR temperature-controlled water bath shaker and agitated (140 rpm) at a certain time. All of the experiments were carried out at $140 \mathrm{rpm}$ at $30^{\circ} \mathrm{C}$. Afterward, supernatant solution was separated from the adsorbent by centrifugation at 2500 for 5 min using IEC Centra CL2 Thermo centrifuge. In order to determine the residue of AO-10 in solution, the absorbance of supernatant solution was measured at maximum wavelength $\left(\lambda_{\text {maks }}\right)$ : $480 \mathrm{~nm}$ using Hitachi U-2000 UV-Vis spectrophotometer. Parameter of adsorption experiment including initial concentration of AO-10 dye (15-60 mg/L), adsorbent

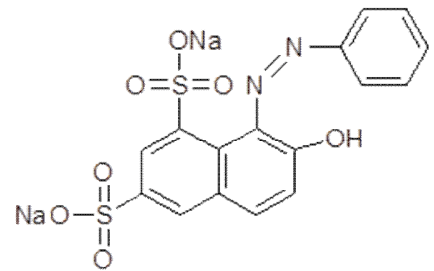

Fig 1. Chemical structure of AO-10 dye

dose (0.25-2 g/L), reaction time (1-120 $\mathrm{min})$, and initial $\mathrm{pH}$ solution (2-10) were investigated. The $\mathrm{pH}$ of the AO-10 solutions were adjusted using a dilute hydrochloric acid solution $(0.1 \mathrm{~N})$ and sodium hydroxide solution $(0.1 \mathrm{~N})$. Effect of ionic strength was conducted using $\mathrm{NaCl}$ salt with concentration ranging from 0 to $0.7 \mathrm{~mol} / \mathrm{L}$.

\section{Analytical measurement of AO-10 dye concentration}

The concentration of residue of $\mathrm{AO}-10$ dye in the solution was determined by inserting the absorbance of the $\mathrm{AO}-10$ sample solutions into $\mathrm{AO}-10$ calibration curve. The calibration curve of the AO-10 was made by plotting the absorbance of $\mathrm{AO}-10$ standard solutions versus their concentration. A high linearity of the calibration curve was found at maximum $30 \mathrm{mg} / \mathrm{L}$ of AO-10 dye, giving an expression: $A=0.029 \mathrm{C}-0.011$, where $A$ and $C$ are the absorbance and concentration of the AO-10 standard solutions, respectively, with coefficient regression $\left(R^{2}\right)$ was found to be 0.999 .

The percentage removal (\%-R) of the AO-10 dye was calculated using Eq. 1, while the amount of dye adsorbed at equilibrium $\left(\mathrm{q}_{\mathrm{e}}\right)$ was calculated from the mass balance equation (Eq. 2):

$\%-R=\left(\frac{C_{0}-C_{t}}{C_{0}}\right) \times 100$

$\mathrm{q}_{\mathrm{e}}=\left(\mathrm{C}_{\mathrm{o}}-\mathrm{C}_{\mathrm{e}}\right) \mathrm{V} / \mathrm{m}$

where $\mathrm{C}_{\mathrm{o}}(\mathrm{mg} / \mathrm{L})$ is initial concentration of $\mathrm{AO}-10$ dye solution, $C_{t}(\mathrm{mg} / \mathrm{L})$ concentration of dye after time $t_{(\mathrm{min})}$, $\mathrm{C}_{\mathrm{e}}$ is the liquid phase dye concentration at equilibrium $(\mathrm{mg} / \mathrm{L}) ; \mathrm{V}$ is volume of dye solution used $(\mathrm{L})$ and $\mathrm{m}$ is the mass of sorbent used $(\mathrm{g})$.

\section{pH point of zero charge}

The $\mathrm{pH}$ point of zero charge $\left(\mathrm{pH}_{\mathrm{pzc}}\right)$ of $\mathrm{CeO}_{2}-\mathrm{NPs}$ were determined using the $\mathrm{pH}$ drift method [20-21]. Typically, a series of $0.01 \mathrm{M} \mathrm{NaCl}$ solution $(15 \mathrm{~mL})$ at different $\mathrm{pH}$ (2-12) were investigated. The presence of $\mathrm{CO}_{2}$ in the solution was removed by a $\mathrm{N}_{2}$ bubbling until a stabile $\mathrm{pH}$ of the solution was achieved, by which this $\mathrm{NaCl}$-free $\mathrm{CO}_{2}$ solution was counted as the initial $\mathrm{pH}$ ). After that, $15 \mathrm{mg}$ of $\mathrm{CeO}_{2}$-NPs were added into each $\mathrm{NaCl}$-free $\mathrm{CO}_{2}$ solutions and kept at room temperature for $24 \mathrm{~h}$ followed by measuring the $\mathrm{pH}$ of the solution 


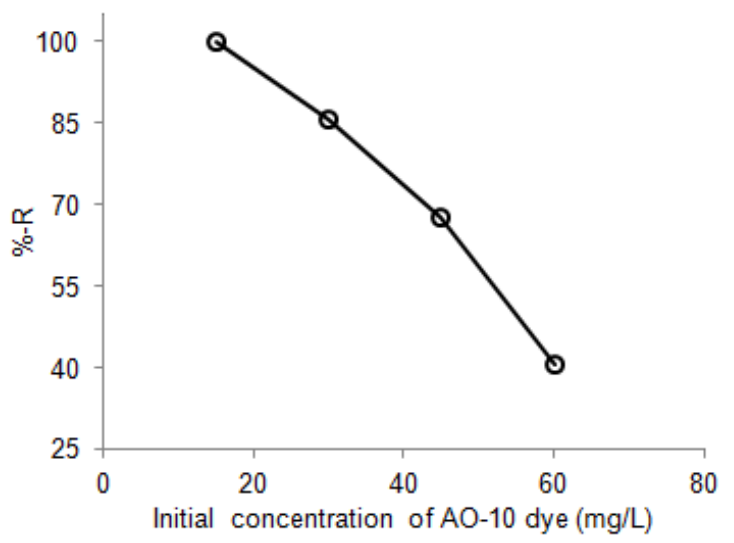

Fig 2. The effect of initial concentration of AO-10 dye on the adsorption activity of $\mathrm{CeO}_{2}-\mathrm{NPS}$

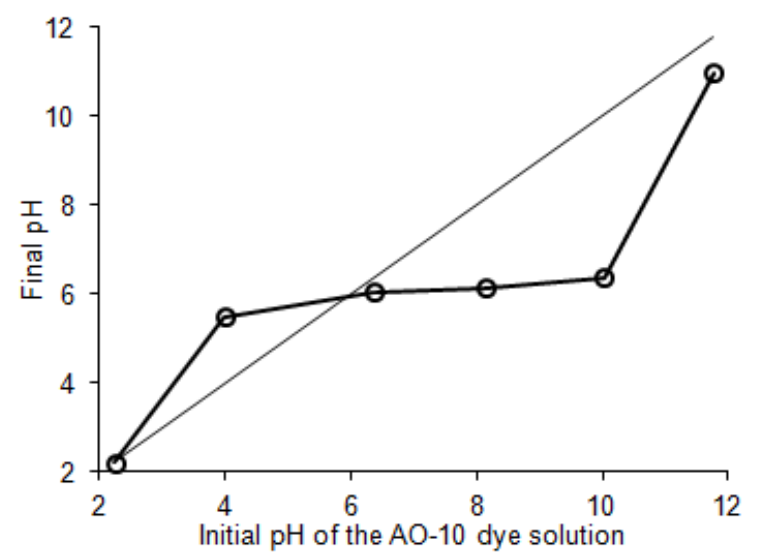

Fig 4. The $\mathrm{pH}_{\mathrm{PzC}}$ of $\mathrm{CeO}_{2}-\mathrm{NPs}$

(this measured $\mathrm{pH}$ values were counted as the final value). The $\mathrm{pH}_{\mathrm{pzc}}$ was taken from the diagonal line of the curve of the final $\mathrm{pH}$ versus initial $\mathrm{pH}$.

\section{RESULT AND DISCUSSION}

\section{Effect of Reaction Parameters}

\section{Effect of initial dye concentration}

The effect of initial concentration of AO-10 dye (15$60 \mathrm{mg} / \mathrm{L}$ ) on $\mathrm{CeO}_{2}-\mathrm{NPs}$ adsorption activity was studied at fixed $\mathrm{pH} 6$ at $30^{\circ} \mathrm{C}$, and the result is shown in Fig. 2. As it can be seen from Fig. 2, the percentage removal of AO-10 dye decreased from $100 \%$ to $40 \%$ by increasing of AO-10 dye concentration from 15 to $60 \mathrm{mg} / \mathrm{L}$. At the lowest concentration (15 mg/L), adsorbate molecules covered all surface active sites of $\mathrm{CeO}_{2}-\mathrm{NPs}$ so that the highest percentage removal of dye could be obtained. On the other hands, the percentage removal of AO-10 dye decreased at higher concentration because the entire surface active sites of adsorbent were saturated by adsorbate. The fully occupation of the surface active sites by the adsorbate may delay the adsorption

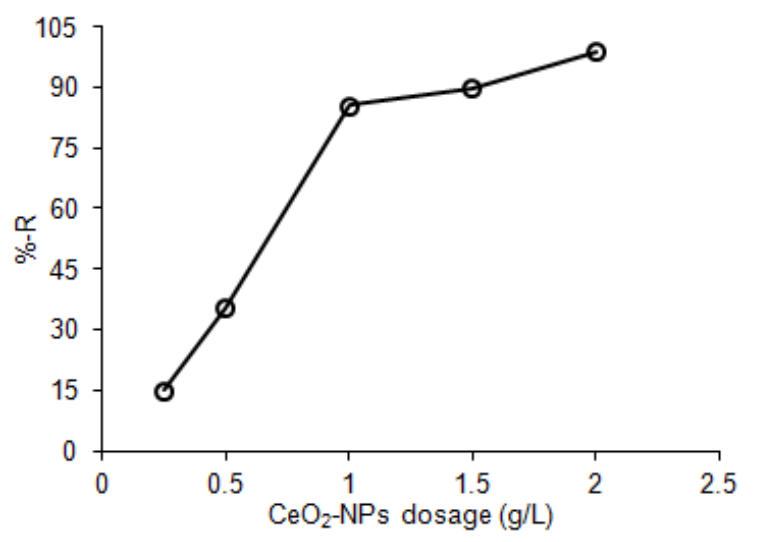

Fig 3. The effect of $\mathrm{CeO}_{2}$-NPs dosage on the percentage removal $\mathrm{AO}-10$ dyes

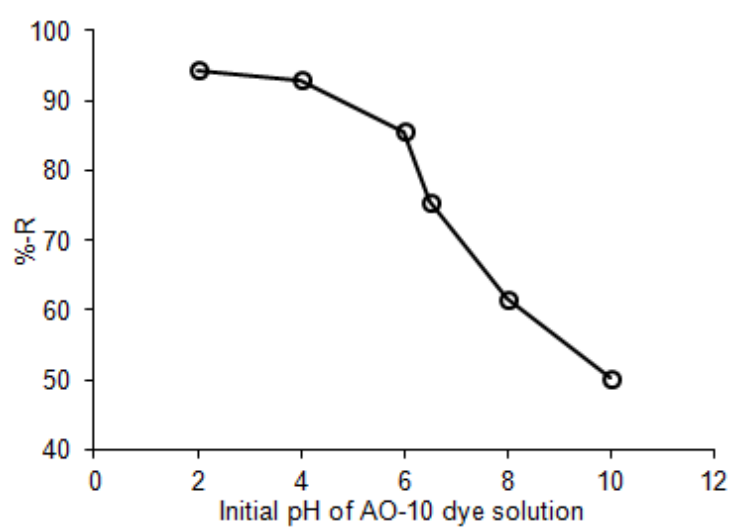

Fig 5. The effect of initial $\mathrm{pH}$ on the percentage removal AO-10 dye

process while a high amount of adsorbate molecules were remained in the bulk solution [22-23].

\section{Effect of adsorbent dosage}

The effect of adsorbent dosage on the adsorption of AO-10 dye was investigated by varying the weight of $\mathrm{CeO}_{2}$-NPs ranging from 0.25 to $2 \mathrm{~g} / \mathrm{L}$, and the result is presented in Fig. 3. It was obviously observed from Fig. 3 that percent removal of AO-10 dye increased from $15 \%$ to $99 \%$ by increasing the dosage of $\mathrm{CeO}_{2}-\mathrm{NPs}$ from 0.25 to $2 \mathrm{~g} / \mathrm{L}$. Increase of the adsorbent dose may contribute to the more availability of the active sites for the adsorption process [24].

\section{Effect of initial $\mathrm{pH}$}

The charge of the adsorbent surface is a function of the $\mathrm{pH}$ of the test solution; hence, it can strongly influence the adsorbent surface toward its ability to adsorb the adsorbate from solution. It has been wellrecognized that the $\mathrm{pH}$ point of zero charge $\left(\mathrm{pH}_{\mathrm{pzc}}\right)$ is the $\mathrm{pH}$ at which the charge of surface adsorbent is zero [25]. The $\mathrm{pH}_{\mathrm{pzc}}$ is an important characteristic for any active adsorbent as it indicates the acidity or basidity of 


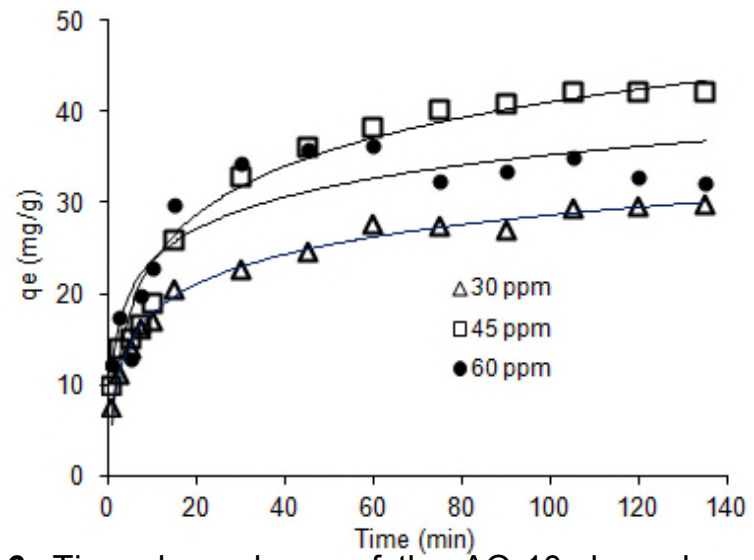

Fig 6. Time dependency of the AO-10 dye adsorption onto $\mathrm{CeO}_{2}$-NPs

the adsorbent and net surface charge of the adsorbent in solution [25-26]. Experimentally, the $\mathrm{pH}_{\mathrm{pzc}}$ of $\mathrm{CeO}_{2}-\mathrm{NPs}$ was found to be about 6 , as shown in Fig. 4. It was highlighted in previous studies [27-28] that the surface of adsorbent positively charged when $\mathrm{pH}$ solution $<\mathrm{pH}_{\mathrm{pzc}}$, and negatively charged when $\mathrm{pH}$ solution $>\mathrm{pH}_{\mathrm{pzc}}$.

Moreover, the effect of initial $\mathrm{pH}$ on the adsorption activity of $\mathrm{CeO}_{2}$-NPs was investigated in the $\mathrm{pH}$ ranging from 2 to 10 and the result is shown in Fig. 5. From the Fig. 5, it was found that the highest percentage removal of $\mathrm{AO}-10$ dye was found at $\mathrm{pH} 2$ and then decreased with the increase of $\mathrm{pH}$ of the $\mathrm{AO}-10$ dye solution. In a solution, the AO-10 dye is preferably dissociated to ion $\mathrm{Na}^{+}$and sulfonate group $\left(\mathrm{RSO}_{3}{ }^{-}\right)$with pKa value of $\mathrm{AO}-$ 10 dye solution is 12.5 [29-30]. Consequently, the $\mathrm{RSO}_{3}{ }^{-}$ of $\mathrm{AO}-10$ dye has negative charged because the $\mathrm{RSO}_{3}{ }^{-}$ could be protonated by $\mathrm{H}^{+}$at $\mathrm{pH}$ difference of solution $(2-10)<\mathrm{pKa}[25-26,28]$. At lower $\mathrm{pH}$ (acidic), the surface of adsorbent become more positively charged $(\mathrm{pH}<$ $\mathrm{pH}_{\mathrm{pzc}}$ ) lead to increase the percentage removal due to strengthening the attractive forces between adsorbate and adsorbent. On the other hands, the surface of adsorbent become more negatively charge along with the increase of $\mathrm{pH}$ solution $\left(\mathrm{pH}>\mathrm{pH}_{\mathrm{pzc}}\right.$ ) lead to decrease the adsorption ability of adsorbent. This decrease phenomenon was due to stronger of the repulsion forces between adsorbate and adsorbent.

\section{Effect of adsorption time}

Fig. 6 shows a time dependency of the adsorption at difference of $\mathrm{AO}-10$ dye concentration. As can be seen from Fig. 6, the adsorption of AO-10 dyes was found to increase with time and achieved its equilibrium after $120 \mathrm{~min}$. Typically, the adsorption of AO-10 dye was rapidly occurred at the first 20 min which was probably due to the presence of large amount accessible surface active sites on $\mathrm{CeO}_{2}$-NPs. After that, the rate of adsorption process was slowly increasing. This slow increase might be due to huge number of surface active

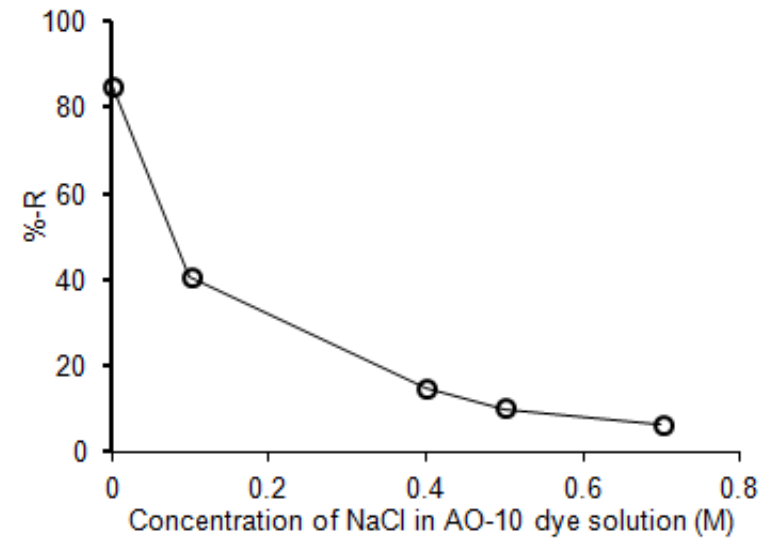

Fig 7. Effect of ionic strength on the adsorption of $\mathrm{AO}-$ 10 dye onto $\mathrm{CeO}_{2}-\mathrm{NPs}$

sites have been covered by the AO-10 dye molecules, where this condition induces the occurrence of the repulsion forces between adsorbate at solid-solution interface $[16,23]$. Moreover, no considerable change on the amount of AO-10 dye adsorbed after $120 \mathrm{~min}$, suggesting that the equilibrium process has been achieved.

\section{Effect of ionic strength}

Fig. 7 demonstrates the effect of ionic strength on the adsorption of $\mathrm{AO}-10$ dye onto $\mathrm{CeO}_{2}-\mathrm{NPs}$. It can be observed from Fig. 7 that the percentage removal of AO-10 dye decreased with increasing the concentration of $\mathrm{NaCl}$ in solution. In the solution, the $\mathrm{Na}^{+}$ions originated from $\mathrm{NaCl}$ has not only neutralized the negative charge of $\mathrm{RSO}_{3}{ }^{-}$group in AO-10 dye, but also results more positive charge of the surface of $\mathrm{CeO}_{2}$ NPs. Such conditions were responsible to reduce the attractive forces between adsorbate molecules and adsorbent. This phenomenon in line with the assumption that the increase of ionic strength by the existence of $\mathrm{NaCl}$ in the solution may cause decrease the adsorption capacity of the adsorbate when an attractive of electrostatic interaction is occurred between adsorbate and adsorbent [16].

\section{Adsorption Isotherm}

Adsorption isotherm study is essential for investigating the interaction mechanism between adsorbate and adsorbent, which further beneficially in evaluating the efficiency of the adsorbent for adsorbate removal. The adsorption isotherm indicates the relationship between the adsorbate in the liquid phase and the adsorbate adsorbed on the surface of the adsorbent at equilibrium at constant temperature. In this study, the adsorption isotherm was evaluated using Langmuir, Freundlich, and Redlich Peterson model. 


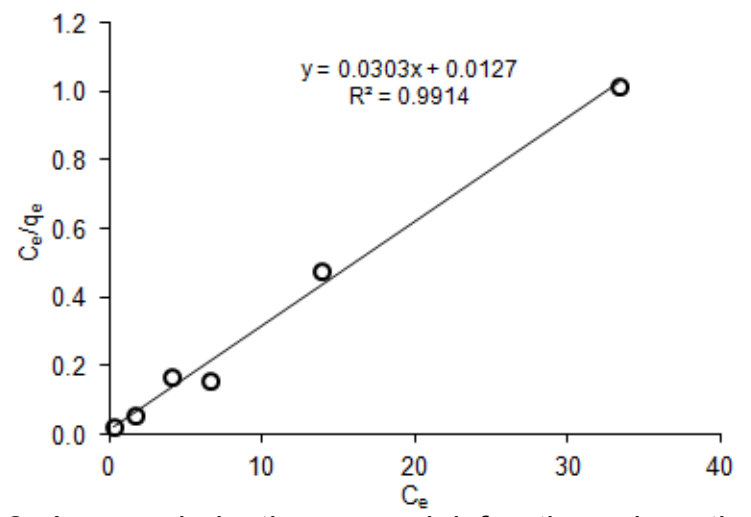

Fig 8. Langmuir isotherm model for the adsorption of AO-10 dye onto $\mathrm{CeO}_{2}$-NPs

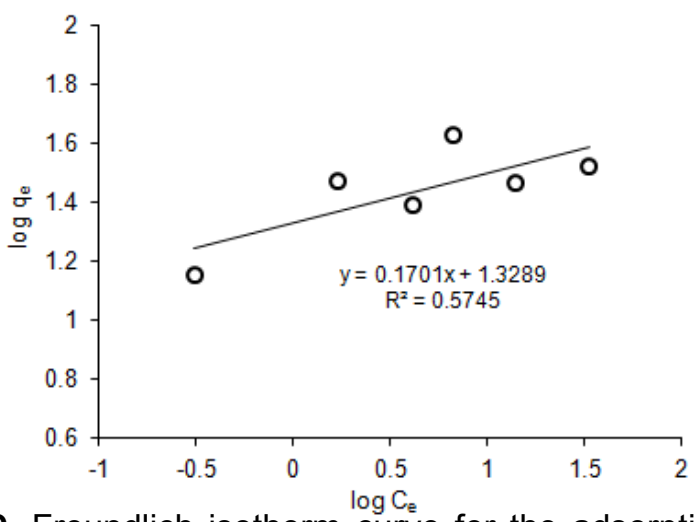

Fig 9. Freundlich isotherm curve for the adsorption of AO-10 dye onto $\mathrm{CeO}_{2}$-NPs

Table 1. Isotherm constant of the models for the adsorption of AO-10 dye onto $\mathrm{CeO}_{2}-\mathrm{NPs}$

\begin{tabular}{cccccc}
\hline \multicolumn{2}{c}{ Langmuir isotherm } & \multicolumn{2}{c}{ Freundlich isotherm } & \multicolumn{2}{c}{ Redlich -Peterson isotherm } \\
\hline Parameter & Value & Parameter & Value & Parameter & Value \\
\hline $\mathrm{Q}_{0}(\mathrm{mg} / \mathrm{g})$ & 33.333 & $\mathrm{~K}_{\mathrm{F}}(\mathrm{mg} / \mathrm{g}) /(\mathrm{L} / \mathrm{mg})^{\mathrm{n}}$ & 21.281 & $\mathrm{~K}_{\mathrm{rp}}(\mathrm{L} / \mathrm{g})$ & 67.12 \\
$\mathrm{~b}(\mathrm{~L} / \mathrm{mg})$ & 2.5 & $\mathrm{n}$ & 5.882 & $\alpha(\mathrm{L} / \mathrm{mg})$ & 1.683 \\
$\mathrm{R}^{2}$ & 0.991 & $\mathrm{R}^{2}$ & 0.574 & $\beta$ & 1.065 \\
& & & & $\mathrm{R}^{2}$ & 0.988 \\
\hline
\end{tabular}

\section{Langmuir isotherm}

Langmuir isotherm is an adsorption model. This isotherm model takes an assumption that the monolayer adsorption occurs at specific homogenous sites within the adsorbent, which expressed by the Eq. (3).

$\mathrm{q}_{\mathrm{e}}=\frac{\mathrm{Q}_{0} \mathrm{bC}_{e}}{1+\mathrm{bC}_{\mathrm{e}}}$

where $q_{e}(\mathrm{mg} / \mathrm{g})$ is the amount of dye adsorbed per unit mass of adsorbent, $\mathrm{C}_{\mathrm{e}}(\mathrm{mg} / \mathrm{L})$ is the concentration of $\mathrm{AO}-$ 10 dye remaining in the solution after equilibrium. $Q_{0}$ is the maximum amount of required to form a complete monolayer on the adsorbent surface at high $\mathrm{C}_{\mathrm{e}}$. The $\mathrm{b}$ is the constant related to the affinity of the binding sites $(\mathrm{L} / \mathrm{mg})$. The linear equation of the Langmuir model can be expressed by Eq. (4).

$\frac{C_{e}}{q_{e}}=\frac{1}{Q_{0} b}+\frac{C_{e}}{Q_{0}}$

Fig. 8 shows the linear graphics of specific adsorption $\left(\mathrm{C}_{\mathrm{e}} / \mathrm{q}_{\mathrm{e}}\right)$ against the equilibrium concentration $\left(\mathrm{C}_{\mathrm{e}}\right)$. This relationship clarifies that the adsorption of AO10 dye on the surface of $\mathrm{CeO}_{2}-\mathrm{NP}$ is in agreement with the Langmuir model. The Langmuir constant, $Q_{0}$ and $b$ were determined from the slope and intercept of the linear plot of Fig. 8. The important characteristic of Langmuir isotherm is a dimensionless constant separation $\left(R_{L}\right)$ which is expressed in the Eq. (5).

$\mathrm{R}_{\mathrm{L}}=\frac{1}{\left(1+\mathrm{bC}_{0}\right)}$

where $\mathrm{C}_{0}$ is the highest initial concentration of adsorbate ( $\mathrm{mg} / \mathrm{L})$, and $\mathrm{b}$ is the constant of Langmuir. The shape of Langmuir isotherm is indicated by the value of $R_{L}$ includes unfavorable $\left(R_{L}>1\right)$, linear $\left(R_{L}=1\right)$, favorable $\left(0<R_{L}<1\right)$, or irreversible $\left(R_{L}=0\right)$ [31]. In this study, the value of $R_{L}$ was found to be 0.00662 , demonstrating that the shape of Langmuir isotherm model for the adsorption of $\mathrm{AO}-10$ dye onto $\mathrm{CeO}_{2}-\mathrm{NPs}$ is favorable. Parameters characteristic of the Langmuir isotherm model obtained in this study are listed in Table 1.

\section{Freundlich isotherm}

Freundlich isotherm is an empirical equation for describing single-component adsorption on heterogeneous surfaces due to due to the variation of functional group presence in the surface. Consequently, the interaction between adsorbate and adsorbent is occurred at different affinity [31-32]. The equation of the Freundlich isotherm model is given by the Eq. (6).

$\mathrm{q}_{\mathrm{e}}=\mathrm{K}_{\mathrm{f}} \mathrm{C}_{\mathrm{e}}^{1 / n}$

where $K_{f}$ and $n$ are Freundlich constants. The $K_{f}(m g / g$ $\left.(\mathrm{L} / \mathrm{mg})^{1 / n}\right)$ is the adsorption capacity of the sorbent, in which the value of $n$ denotes the favorable of the adsorption process, while value of $1 / \mathrm{n}$ (0 to 1$)$ showed the criterion of adsorption intensity or the heterogeneous of the adsorbent surface. The more heterogenic of the adsorbent surface the more favorable of the adsorption condition for Freundlich model. Under this condition, the value of $1 / \mathrm{n}$ approach to 0 . The linear plot (Eq. 7) describing the relationship between $\log q_{e}$ versus $\log C_{e}$ is subjected to determine the $\mathrm{K}_{\mathrm{f}}$ constant and $\mathrm{n}[23,31-32]$. 
Table 2. A maximum monolayer of various adsorbents for AO-10 dye adsorption

\begin{tabular}{llll}
\hline Adsorbents & $\mathrm{Q}_{0}(\mathrm{mg} / \mathrm{g})$ & $\mathrm{T}\left({ }^{\circ} \mathrm{C}\right)$ & Reference \\
\hline $\mathrm{CeO}_{2}-\mathrm{NPs}$ & 33.33 & 30 & This study \\
Thespesia populnea pods carbon & 9.13 & 25 & {$[34]$} \\
Bagasse fly ash & 18.80 & 30 & {$[30]$} \\
$\mathrm{Saw}$ dust & 0.4045 & 35 & {$[35]$} \\
$\mathrm{Mg}-\mathrm{Fe}-\mathrm{CO}_{3}$ layer double hydroxide & 72.08 & 25 & {$[12]$} \\
Monoamine modified magnetic silica & 60.02 & 25 & {$[14]$} \\
Waste sugarcane bagasse carbon & 3.92 & 40 & {$[36]$} \\
\hline
\end{tabular}

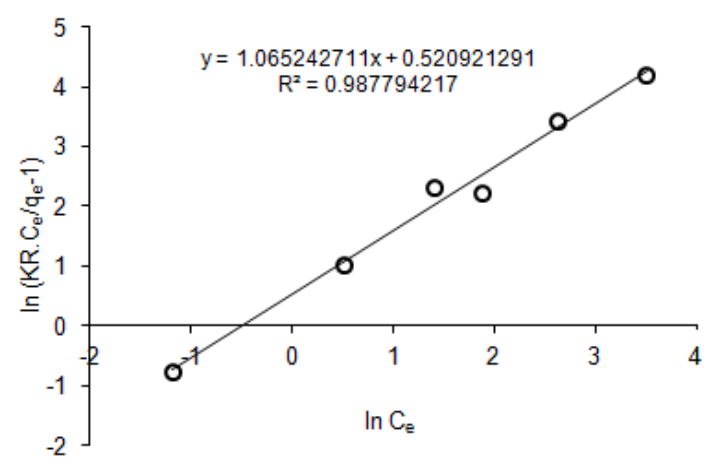

Fig 10. Redlich-Peterson isotherm for the adsorption of AO-10 dye onto $\mathrm{CeO}_{2}-\mathrm{NPs}$

$\log q_{e}=\log K_{f}+\left(\frac{1}{n}\right) \log C_{e}$

The value of $K_{f}$ and $n$ are listed in Table 1, which was calculated from the intercept and the slope of the linear graphic of the Fig. 9.

\section{Redlich Peterson isotherm}

Redlich-Peterson isotherm is the adsorption model which is used to compromise the limitation of both the Langmuir and Freundlich isotherm models. Thus, the equation of the Redlich-Peterson model combines parameters from the Langmuir and Freundlich model. The adsorption mechanism of Redlich-Peterson model follows a non ideal monolayer adsorption that is a hybrid mechanism from the Langmuir and Freundlich isotherm $[28,33]$. Redlich-Peterson model is expressed by the Eq. 8.

$\mathrm{q}_{\mathrm{e}}=\frac{\mathrm{K}_{\mathrm{rp}} \mathrm{C}_{\mathrm{e}}}{1+\alpha \mathrm{C}_{\mathrm{e}}^{\beta}}$

where $q_{e}$ is the amount of adsorbate adsorbed per unit mass of adsorbent $(\mathrm{mg} / \mathrm{g}), \mathrm{C}_{\mathrm{e}}$ is the adsorbate concentration remained in solution after equilibrium (mg/L). The Redlich-Peterson isotherm constants including $\mathrm{K}_{\mathrm{rp}}(\mathrm{L} / \mathrm{g}), \alpha(\mathrm{L} / \mathrm{mg})$, and $\beta$ can be determined from the Eq. 8. The $\beta$ value is exponential value range from 0 to 1 . Adsorption model follows the Langmuir model when the $\beta$ value is 1 , while when the $\beta$ value is 0 , the adsorption model follows the Henry's law.
The linear graphic of Redlich-Peterson is given by the following equation (Eq. 9).

$\ln \left(\frac{\mathrm{K}_{\mathrm{rp}} \mathrm{C}_{\mathrm{e}}}{\mathrm{q}_{\mathrm{e}}}-1\right)=\beta \ln \left(\mathrm{C}_{\mathrm{e}}\right)+\ln (\alpha)$

The values of $K_{r p}, \alpha$, and $\beta$ were calculated from intercept and slope of the linier plot in the Fig. 10 and the results are listed in Table 1. Based on the data as listed in Table 1, correlation coefficient of isotherm Langmuir model $\left(R^{2}: 0.991\right)$ is higher than Freundlich and Redlich-Peterson model, indicating that the adsorption of $\mathrm{AO}-10$ dye onto $\mathrm{CeO}_{2}-\mathrm{NPs}$ had good agreement with the Langmuir isotherm. Thus, it can be suggested that the AO-10 dye was absorbed on the homogenous surface active site of adsorbent via a development of monolayer adsorbate mechanism. The adsorption capacity of monolayer generated by the Langmuir model was found to be $33.33 \mathrm{mg} / \mathrm{g}$ at $30^{\circ} \mathrm{C}$

Table 2 compares the adsorption capacities of the synthesized $\mathrm{CeO}_{2}-\mathrm{NPs}$ with various types of adsorbent for AO-10 dye removal. As can be seen, the adsorption capacity of $\mathrm{CeO}_{2}-\mathrm{NPs}$ for $\mathrm{AO}-10$ adsorption is 33.33 $\mathrm{mg} / \mathrm{g}$, which was higher than Thespesia populnea pods carbon, bagasse fly ash, saw dust, and waste sugarcane bagasse carbon. On the other hands, the value of $\mathrm{Q}_{0}$ of $\mathrm{CeO}_{2}-\mathrm{NP}$ is smaller than $\mathrm{Mg}-\mathrm{Fe}-\mathrm{CO}_{3}$ layer double hydroxide and monoamine modified magnetic silica (MAMMS). This finding indicates that the $\mathrm{CeO}_{2}$-NPs was more efficient as adsorbent for AO10 dye removal than other as listed in Table 1, except for $\mathrm{Mg}-\mathrm{Fe}-\mathrm{CO}_{3}$ and monoamine modified magnetic silica (MAMMS) adsorbent.

\section{CONCLUSION}

In this study, $\mathrm{CeO}_{2}$-NP was found as an active material for removing $\mathrm{AO}-10$ dye from aqueous water using batch system. Percentage removal of AO-10 dye was highly affected by the parameter reaction used. The favor condition for the adsorption of AO-10 dye was found at initial $\mathrm{pH} 2$, giving 94\% percentage removal. It was observed that the adsorption of capacity follows Langmuir isotherm type with 33.33 $\mathrm{mg} / \mathrm{g}$ maximum monolayer adsorption capacity. 


\section{REFERENCES}

1. Priya, M.S., Divyashree, K., Goswami, C., Prabha, M.L., and Babu, A.K.S., 2013, Int. J. Eng. Adv. Technol., 2 (4), 913-918.

2. Pavanelli, S.P., Bispo, G.L., Nascentes, C.C., and Augusti, R., 2011, J. Braz. Chem. Soc., 22 (1), 111119.

3. Annadurai, G., Juang, R.S. and Lee, D.J., 2002, J. Hazard. Mater., B92, 263-274.

4. Olaniyi, I., Raphaeel, O., and Onyebuchi, N.J., 2012, Arch. Appl. Sci. Res., 4 (1), 406-413.

5. Rasul, M.G., Faisal, I., and Khan, M.M.K., 2006, Int. J. Environ. Pollut., 28 (1-2), 144-161.

6. Namasivayam, C., Radhika, R., and Suba, S., 2001, Waste Manage., 21 (4), 381-387.

7. Hariharan, C., 2006, Appl.Catal., A, 304, 55-61.

8. Sun, Q., and Yang, L., 2003, Water Res., 37 (7), 1535-1544.

9. Nigam, P., Banat, I.M., Singh, D., and Marchant, R., 1996, Proc. Biochem., 31 (5), 435-442.

10. Pandit, P., and Basu, S., 2004, Ind. Eng. Chem. Res., 43 (24), 7861-7864.

11. Masykur, A., Santosa, S.J., Siswanta, D., and Jumina, 2014, Indo. J. Chem., 14 (1), 63-70.

12. Abdelkader, N.B-H., Bentouami, A., Derriche, Z., Bettahar, N., and de Ménorval, L.-C, 2011, Chem. Eng. J., 169 (1-3), 231-238.

13. Zuas, O., and Budiman, H., 2013, Nano-Micro Lett., 5 (1), 26-33.

14. Atia, A.A., Donia, A.M., and Al-Amrani, W.A., 2009, Chem. Eng. J., 150 (1), 55-62.

15. Meral, K., and Metin, O., 2014, Turk. J. Chem., 1-8.

16. Konicki, W., Sibera, D., Mijowska, E., LendzionBieluń, Z., and Narkiewicz, U., 2013, Colloid Interface Sci., 398, 152-160.

17. Salehi, R., Arami, M., Mahmoodi, N.M., Bahrami, H., and Khorramfar, S., 2010, Colloids Surf., B, 80 (1), 86-93.

18. Zuas, O., Abimanyu, H., and Wibowo, W., 2014, Proc. Appl. Ceram., 8 (1), 39-46.

19. AMRESCO Safety Data Sheet of Acid Orange 10, 2014, http://www.amresco-inc.com/media.acux?path=/
media/products/msds/MSDS-E783.pdf, accessed on 4 June 2014.

20. Lopez-Ramon, F.M., Stoeckli, V., Moreno-Castilla, C., and Carrasco-Marin, F., 1999, Carbon, 37 (8), $1215-1221$.

21. Al-Degs, Y.S., El-Barghouthi, M.I., El-Sheikh, A.H., and Walker, G.M., 2008, Dyes Pigm., 77 (1), 1623.

22. Khezami, L., and Capart, R., 2005, Hazard. Mater., 123 (1-3), 223-231.

23. Ghaedi, M., Heidarpour, Sh., Kokhdan, S.N., Sahraie, R., Daneshfar, A., and Brazesh, B., 2012, Powder Technol., 228, 18-25.

24. Garg, V.K., Gupta, R., Yadav, A.B., and Kumar, R., 2003, Bioresour. Technol., 89 (2), 121-124.

25. Khare, P., and Kumar, A., 2012, Appl. Water Sci., 2 (4), 317-326.

26. Dursun, G., Ciçek, H., and Dursun, A.Y., 2005, J. Hazard. Mater., 125 (1-3), 175-182.

27. Dąbrowski, A., Podkościelny, P., Hubicki, Z., and Barczak, M., 2005, Chemosphere, 58 (8), 10491070.

28. Liu, Q.-S., Zheng, T., Wang, P., Jiang, J.-P., and Li, N., 2012, Chem. Eng. J., 157 (2-3), 348-356.

29. Cheung, W.H., Szeto, Y.S., and Mckay, G., 2009, Bioresour. Technol., 100 (3), 1143-1148.

30. Mall, I.D., Srivastava, V.C., and Agarwal, N.K., 2006, Dyes Pigm., 6 (3), 210-223.

31. Tan, L.A.W., Ahmad, A.L., and Hameed, B.H., 2009, J. Hazard. Mater., 164 (2-3), 473-482.

32. Hameed, B.H., and El-Khaiary, M.I., 2008, J. Hazard. Mater., 157 (2-3), 344-351.

33. Ho, Y-S., Malarvizhi, R., and Sulochana, N., 2009, J. Environ. Prot. Sci., 3, 111-116.

34. Arulkumar, M., Sathishkumar, P., and Palvannan, T., 2011, J. Hazard. Mater., 186 (1), 827-834.

35. Singh, J., Uma, Mishra, N. S., Banerjee, S., Gusain, D., and Sharma, Y.C., 2011, Appl. Sci. Environ. Sanit., 6 (3), 2732-2743.

36. Tsai, W.T., Chang, C.Y., Lin, M.C., Chien, S.F., Sun, H.F., and Hsieh, M.F., 2011, Chemosphere, 45 (1), 51-58. 